\title{
Anabases
}

ANABASES Traditions et réceptions de l'Antiquité

19 | 2014

Varia

\section{Thucydide parmi les guerres : les voix du sang}

\section{Francisco Murari Pires}

\section{OpenEdition}

Journals

Édition électronique

URL : http://journals.openedition.org/anabases/4672

DOI : $10.4000 /$ anabases.4672

ISSN : 2256-9421

\section{Éditeur}

E.R.A.S.M.E.

\section{Édition imprimée}

Date de publication : 1 avril 2014

Pagination : 207-225

ISSN : 1774-4296

\section{Référence électronique}

Francisco Murari Pires, «Thucydide parmi les guerres : les voix du sang », Anabases [En ligne], 19

2014, mis en ligne le 01 avril 2017, consulté le 21 octobre 2019. URL : http://journals.openedition.org/ anabases/4672 ; DOI : 10.4000/anabases.4672 
Anabases 19 (2014), p. 207-225

\section{Thucydide parmi les guerres : les voix du sang}

Francisco Murari Pires

a dream dreamed by Thucydides

(William Faulkner, Nympholepsy)

Lie quiet, Divus

(Ezra Pound, The Cantos)

there are times when silence is imperative for us

to listen the music behind the raindrops

(Theo Angelopoulos, The Suspended Step of the Stork)

\section{Ktema es aei :}

les ambiguïtés de la voix et les échos du silence

$$
\begin{array}{r}
\text { In the ancients every man has found } \\
\text { what he needed or desired - } \\
\text { especially himself } \\
\text { (F. Schelling, Athenäum) }
\end{array}
$$

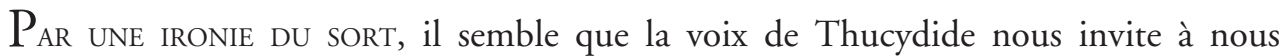
prémunir contre les misères et les infortunes inhérentes à l'histoire de la condition humaine, pour nous permettre ainsi, par la similitude entre les événements anciens et contemporains, de mieux percevoir leurs effets. Justement, c'est en tant que ktema es $a e i-$ "acquisition pour toujours »-, connaissance historique d'une utilité permanente, 
toujours actuelle, que Thucydide fait ressortir la valeur de l'histoire de la guerre qu'il raconte ${ }^{1}$.

Dans la perspective de cette conception thucydidéenne, l'histoire représente fondamentalement l'instance privilégiée du savoir humain, concernant les hommes et pour les hommes présents et à venir, de tous les temps. Cependant, quelle serait au juste cette valeur si riche en enseignements pour l'histoire de l'humanité ? Le savoir clairvoyant que son histoire proclame avoir atteint, grâce à l'observation de la guerre du Péloponnèse, serait-il réellement apte à projeter sa valeur sur toute l'histoire humaine, mettant ainsi à la disposition des hommes futurs des directives leur permettant de corriger, dans l'actualité de leur propre histoire, ces erreurs du passé que l'historien ancien met en cause dans le contexte de la guerre dont il fut jadis un des contemporains ? Ou plutôt, Thucydide anticiperait-il ainsi de façon prémonitoire la répétition persistante au long de l'histoire des mêmes erreurs, faites par des hommes incorrigibles de nature, comme le suggère Chateaubriand dans un passage du Génie du Christianisme : "Thucydide retraça avec sévérité les maux causés par les dissensions politiques, laissant à la postérité des exemples dont elle ne profite jamais ${ }^{2}$ " ? Une idée quelque peu similaire est formulée par Marx, qui révélait, dans une lettre adressée à son disciple Ferdinand Lassalle, la raison pour laquelle il était alors en train de lire Thucydide (le 29 mai 1861) : " In order to mitigate the profound bad mood caused by the situation, uncertain in every sense, I am reading Thucydides. At least these ancients always remain new ${ }^{3}$. " La conviction (et l'orgueil) du savoir historique thucydidéen reflèterait-elle donc un optimisme empreint d'espérance relativement à une amélioration, sinon un perfectionnement, de la nature humaine ou, à l'inverse, accuserait-elle un pessimisme plein d'amertume, sans illusions ni croyances?

Par ailleurs, quelle est exactement cette clairvoyance historiographique qui, cristallisée par la mémoire historique de la perception thucydidéenne, serait investie

1 Thucydide, La Guerre du Péloponnèse I, 22, 4 (traduction de Léon Bodin et Jacqueline de Romilly, Paris, Les Belles Lettres, Cuf, 1955, p. 106-108).

2 Livre III, chapitre 3, dans l'Essai sur les révolutions. Génie du Christianisme, Paris, Gallimard, 1978, p. 836. Machiavel l'avait dit aussi en termes généraux : "Celui qui considère les choses présentes et les anciennes comprend facilement que dans toutes les cités et dans tous les peuples il y a les mêmes désirs et les mêmes humeurs, et qu'ils y ont toujours été. De sorte qu'il est facile, pour celui qui examine diligemment les choses passées, de prévoir, dans tout État, les choses futures, et d'y apporter ces remèdes qui ont été utilisés par les Anciens ou, s'il n'en trouve pas, d'en envisager de nouveaux en se fondant sur la similitude des événements. Mais, comme ses considérations sont négligées ou ne sont pas comprises par ceux qui lisent ou, si elles sont comprises par eux, ne sont pas connues par ceux qui gouvernent, il s'ensuit qu'il y a toujours les mêmes désordres en tout temps " (par la traduction française de Alessandro Fontana et Xavier Tabet : N. Machiavel, Discours sur la première décade de Tite-Live, Paris, 2004, p. 187).

3 M. Musto, "The Rediscovery of Karl Marx ", International Review of Social History 52 (2007), p. 491. 
d'une puissance cognitive telle, concernant la réalité des modes d'action humains dans le monde, que sa valeur pourrait ainsi traverser le temps historique, renouvelant sans cesse, au fil de ses contemporanéités successives, une force d'orientation jamais démentie ? Le récit thucydidéen constituerait-il ainsi une sorte de science des significations transparentes des actes humains, appréhendés dans et par leur immanence factuelle même ? Les faits historiques tels qu'ils sont inscrits dans le récit de Thucydide auraient-ils une clarté de sens si totale qu'elle puisse rendre pleinement universels ses enseignements?

L'histoire de ces résonances qui actualise le ktema es aei s'étend déjà sur plus de deux millénaires en une succession de voix, multiples et portées par le souci de trouver une réponse à la prolixité du silence original ${ }^{4}$. Au long de cette traversée de la mémoire thucydidéenne, quelle valeur utile chaque époque a-t-elle actualisée dans sa propre relecture et, par là, dans une configuration spécifique du sens de ce savoir historique thucydidéen si singulier?

Pendant longtemps, du XIX ${ }^{\mathrm{e}}$ jusqu'aux premières décennies $\mathrm{du} \mathrm{XX}^{\mathrm{e}}$ siècle, une image de Thucydide a été diffusée, par laquelle son œuvre était jugée comme un mode exemplaire d'écriture de l'Histoire. Il était habituel d'y déceler les principes (modernes) de scientificité historiographique : le primat de la vérité des faits dans leur singularité d'événements chronologiquement ordonnancés ; l'exercice de la capacité critique structurée par la méthode analytique reposant sur le respect rigoureux de la vérité ; l'herméneutique guidée par la thèse de la causalité immanente de l'histoire ; l'épistémologie fondée sur l'idéal d'objectivité ; et même, enfin, ce que nous pourrions nommer le savoir aspirant à la formulation de lois générales des phénomènes historiques ${ }^{5}$.

Arnaldo Momigliano situe aux alentours de 1860 le moment où la pensée historiographique moderne gagne de l'indépendance par rapport à ses modèles classiques, et à Thucydide en particulier. Les méthodes et les champs vers lesquels l'histoire hégélienne ou marxiste, culturelle, sociologique ou anthropologique ${ }^{6}-$ se dirigeait désormais, la faisaient se libérer des modèles antiques. Justement on constatait à cette époque-là toute une série d'avancées épistémologiques de la discipline historique, qui était désormais plus résolument configurée comme une science : la culture du primat du texte comme document ; la césure entre le présent et le passé dans la constitution de l'objectivité ; la superposition de la catégorie d' "observation indirecte » (relevant de

4 F. Murari Pires, Modernidades Tucidideanas, São Paulo, Edusp-Fapesp, 2007, p. 11-30.

5 Nous renvoyons aux commentaires de H.-P. STAHL, Thucydides. Man's Place in History, Swansea, The Classical Press of Wales, 2003, p. 12. Voir aussi F. Murari Pires, "Thucydidean modernities : history between science and art ", in Brill's Companion to Thucydides, edited by Antonios Rengakos and Antonis Tsakmakis, Leiden-Boston, Brill, 2006, p. 811.

6 A. Momigliano, "The place of ancient historiography in modern historiography ", in Settimo Contributo alla Storia degli Studi Classici e del Mondo Antico, Rome, 1984, p. 28. 
la scientificité moderne) à celle d' " autopsie " (propre à l'historiographie ancienne) ${ }^{7}$; la systématisation normative des opérations de méthodologie critique. Par le recoupement de tous ces principes, la réflexion historiographique moderne essaie de prendre ses distances par rapport à la figuration qui faisait de Thucydide le modèle de l'écriture de l'histoire ${ }^{8}$.

Au cœur du $\mathrm{XX}^{\mathrm{e}}$ siècle, des croisades persistantes dirigées contre l'histoire dite " positiviste " héritée du XIX siècle, spécialement la condamnation du "wie es eigentlich gewesen " rankéen, atteignirent en même temps Thucydide, jetant le discrédit sur la réputation de son histoire et incitant les historiens contemporains à s'écarter de son modèle ${ }^{9}$. Il n'y a pas si longtemps, précisément parce qu'il était associé à l'" histoire militaire " ou à l'" histoire attachée au pouvoir ", Thucydide se vit discrédité ; c'était la conséquence des avancées épistémologiques du milieu du $\mathrm{Xx}^{\mathrm{e}}$ siècle ${ }^{10}$. Par ailleurs, dans le domaine de la science politique, notamment de la réflexion suscitée par les dilemmes issus des dangers de la guerre froide, spécialement dans les milieux universitaires nord-américains, l'actualisation de Thucydide fut sévèrement remise en question. Tout d'abord, pendant les années 1950-1970, tant les réalistes que, tout de suite après eux, les néoréalistes mirent l'accent sur la nécessité de fonder une nouvelle " science de la politique ", enfin libérée des naïvetés du vieux libéralisme classique qui avait été submergé par les marais totalitaires de la première moitié $\mathrm{du} \mathrm{Xx}^{\mathrm{e}}$ siècle. Or c'est précisément dans l'ancienne figure de l'autorité thucydidéenne qu'ils ancraient encore les projections de leurs nouvelles théories. Néanmoins, immédiatement après eux, et en raison des désillusions américaines suscitées par la guerre du Vietnam, en des temps où la vogue moraliste du " politiquement correct " était déjà de mise, on voulut purifier l'éthique thucydidéenne des contaminations résultant de son identification moderne avec des noms comme ceux de Machiavel ou de Hobbes, tous les deux infectés par la Realpolitik, dont l'association avec Thucydide risquait de l'entraîner avec eux en enfer ${ }^{11}$.

Toujours est-il que la proclamation de Thucydide qui fait de son histoire un ktema es aei, savoir perçu comme un bien précieux pour l'humanité, suscita au sein de la tradition occidentale de la pensée historiographique une série de doutes, d'interrogations et de polémiques. Mais, à toutes ces questions posées par la critique moderne,

$7 \quad$ Voir en ce sens les analyses de B. Boulay, "Effets de présence et effets de vérité dans l'historiographie ", Fabula [http://www.fabula.org/atelier.php?Effetsdepresence].

8 F. Murari Pires, "Thucydidean modernities : history between science and art ", op. cit., p. 829-830.

9 F. Hartog, "L'œil de Thucydide et l'histoire "véritable" ", Poétique 49, 1982, p. 26-27 ;

F. Murari Pires, Modernidades Tucidideanas, São Paulo, Edusp-Fapesp, 2007, p. 21.

10 F. Murari Pires, "Thucydidean modernities : history between science and art ", op. cit., p. 831-834.

11 F. Murari Pires, "Machiavel, la cour des Antiques et (le dialogue avec) Thucydide ", Dialogues d'histoire ancienne 34/1, 2008, p. 14-25. 
l'œuvre de Thucydide n'apporte de réponses que sous une forme négative, par l'indétermination de ses silences. Or ces silences, c'est nous-mêmes, les lecteurs de Thucydide, qui les faisons ressortir a posteriori dans le texte, en conformité avec les doutes nés de l'(in)satisfaction de notre propre (in)compréhension de ce que Thucydide a écrit. Nous-mêmes, lecteurs post-thucydidéens, mettons l'accent sur les vides textuels - ou ce que nous interprétons comme tels - qui auraient passé sous silence les informations et les considérations qui permettraient d'en mieux remplir ou d'en mieux compléter le sens. Les enquêtes ayant pour visée de rendre pleines ces réponses que Thucydide aurait laissées en suspens dans son texte sont donc forcées de lui prêter leurs propres voix, actualisées en d'autres temps et mues par la connaissance d'autres histoires (avec leurs idées, leurs conceptions, leurs préceptes), tout en ayant pour prétention de faire entendre les échos du propos original.

Pour (r)établir ce (supposé) propos original, on travaille donc sur les interstices des silences projetés dans l'œuvre. L'herméneutique moderne du texte thucydidéen essaie alors de déterminer positivement les propositions qui, dans le texte original, correspondraient à des vides dus aux imprécisions, indécisions, ambiguïtés ou ambivalences de la narration thucydidéenne ${ }^{12}$. L'historien moderne imiterait ainsi Thucydide, assumant la mission qu'il s'était originalement imposée, ainsi conçue selon la formule rankéenne : "dire le fait en nous faisant voir comment les choses se sont effectivement passées ». On ambitionne d'appréhender le fait historique, en tant que perception épurée de toute contradiction, ambiguïté et incertitude. Pour ce faire, on élimine du récit certaines données factuelles, pour en imposer d'autres, (re)construites juste à cette fin ${ }^{13}$.

12 Voir pour l'argumentation concernant ces réflexions ce que nous avons exposé dans "The rhetoric of method ", Ancient History Bulletin 12.3 (1998) p. 106-112, et dans "Leões alados e círculos triangulares " (F. Murari Pires, Mithistoria, São Polo, 1999, p. 441-463), titre qui fait référence à un commentaire de Hannah Arendt dans le prologue de The Human Condition sur une formule originellement employée par Erwin Schrödinger (H. ARENDT, 1981, p. 111).

13 De sorte que l'historien moderne réitère ainsi les confusions du jeu ambigu supposé par les déclarations " méthodologiques " de Thucydide, par lesquelles on assimile ce qui concerne l'objet (la disposition des données factuelles de la part de ceux qui étaient présents) au sujet de la praxis historiographique (la construction du sens de l'événement). Voir F. Murari Pires, "Thucydide et l'assemblée sur Pylos (IV.26-28) : rhétorique de la méthode, figure de l'autorité et détours de la mémoire ", The Ancient History Bulletin 1 (2003), p. 129-131. 


\title{
Les avatars bellicistes du ktema es aei : quelques chroniques américaines
}

\author{
And so the war had come down to words. \\ It was fought in terminology across a table. \\ It was contested in sentences. [...] \\ Language is war by other means \\ E.L. Doctorow (The March)
}

Pour s'informer sur la route maritime qui le ramènerait à Ithaque, Ulysse est allé consulter Tirésias dans l'Hadès. Circé lui avait indiqué comment il devait procéder : à l'entrée du séjour infernal, faire un trou pour y verser le sang de victimes animales. Alors, assis au bord de ce trou, il devrait attendre l'arrivée des âmes des morts qui y habitaient, en ne permettant qu'à Tirésias d'en boire. Celui-ci lui dirait les orientations qu'il devait suivre. Dans cette conversation avec le sage devin, s'est révélée la raison de cet étrange rituel de nourrir avec le sang des vivants la voix et la parole de morts : ils diraient la vérité 14 .

Le sang de nos histoires guerrières constitue l'aliment qui revigore l'âme de Thucydide, en lui redonnant sa voix. Mais quels que soient l'Hadès (ou l'Enfer) et l'Élysée (ou le Paradis) dans lesquels nous essayons de situer la figure de Thucydide, son esprit ainsi réanimé fait résonner des voix multiples et des propos divers, foncièrement actuels en chacun des temps présents, comme le suggère la réflexion formulée il y a deux siècles par Friedrich Schlegel : "In the ancients every man has found what he needed or desired-especially himself ${ }^{5}$."

Le 5 septembre 1774 se réunissait à Philadelphie le First Continental Congress pour débattre et décider des directives à prendre en vue de délimiter l'autonomie des colonies américaines. À la suite de ces délibérations, qui s'étaient étendues sur plus d'un mois (jusqu'au 26 octobre), un Comité rédigea les actes qui fixaient la définition du programme souhaité : une Petition to the King, une Address to the People of England, et un Memorial to the People of British America ${ }^{16}$.

Quelque deux mois après, le 20 janvier 1775, lors d'un discours prononcé à la House of Lords, William Pitt (Lord Chatham) reconnaissait, dans les échanges survenus lors du "General Congress at Philadelphia ", un niveau de rhétorique délibérative qui les rendait égaux (sinon même supérieurs) à ceux contenus dans Thucydide :

14 Homère, Odyssée X, 487-540.

15 F. Schlegel, "Aphorisms ", in The German Classics of The Nineteenth And Twentieth Centuries, vol. IV (1913), p. 178.

16 E. Wolf, "The authorship of the 1774 address to the king restudied ", The William and Mary Quarterly, Third Series 22.2 (1965), p. 189-224. 
When your Lordships look at the papers transmitted us from America; when you consider their decency, firmness, and wisdom, you cannot but respect their cause, and wish to make it your own - for myself I must declare and avow that, in all my reading and observation, and it has been my favourite study - I have read Thucydides, and have studied and admired the master states of the world - that for solidity of reasoning, force of sagacity, and wisdom of conclusion, under such a complication of difficult circumstances, no Nation or body of men can stand in preference to the General Congress at Philadelphia ${ }^{17}$.

Ainsi se trouvait invoquée, à la veille de la Révolution américaine, la figure d'un Thucydide parlementaire, qui, plus tard, durant les années de la Révolution française en proie à la Terreur, serait consacrée par Pierre-Charles Levesque dans un passage de sa préface de la traduction de l'historien ancien qu'il publiait :

Thucydide est, de tous les historiens, celui qui doit être le plus étudié dans les pays où tous les citoyens ont quelque part au gouvernement. Un membre très-éclairé du parlement d'Angleterre disait qu'il ne pouvait s'agiter dans les chambres aucune question sur laquelle on ne trouvait des lumières dans Thucydide ${ }^{18}$.

Mais cette stature d'autorité parlementaire attribuée à Thucydide suscitait aussi, selon ce qu'exprimèrent le $1^{\mathrm{er}}$ avril 1775 les politiques anglais (Address of the People of Great Britain to the Inhabitants of America), une mise en garde adressée en ces termes aux révolutionnaires américains, afin de leur enseigner les bonnes leçons de l'histoire thucydidéenne :

" for if you are permitted to throw off these badges of supremacy, as madmen may call them, you are that instant independent States ; you will form yourselves into independent Principalities, Republics, and we fear Anarchies. A new political system will arise, not in Europe alone, but in the world. Foreign Nations will intrigue in your Assemblies ; you will engage in wars with them, with us, and with your sister Provinces. This is not all. In Governments formed suddenly, and which, therefore, must be imperfect, you will fall into dissensions among yourselves, so that all the miseries of foreign, of civil, and of domestic war, will be accumulated on your heads. We wish that your Congress, which is

17 P. Force, American Archives, Fourth Series, volume 1, 1837, p. 1497-1498. Voir aussi : Memoir of the Life of Richard Henry Lee (1825), The North American Review 22.51 (1826), p. 383, et R.M. Gummere, "The heritage of the classics in colonial North America. An essay on the Greco-Roman tradition ", Proceedings of the American Philosophical Society 99.2 (1955), p. 77.

18 P. Ch. Levesque, Histoire de Thucydide, fils d'Olorus, traduite du grec par Pierre Charles Levesque, Paris, Gail et Aubin 1795, p. xix. Voir spécialement : N. Loraux et P. VIDALNAQUET, "La formation de l'Athènes bourgeoise : essai d'historiographie 1750-1850 ", in Classical Influences on Western Thought, edited by R.R. BOLgAR, Cambridge, Cambridge University Press, 1979, p. 194. 
so learned in the principles of the great Montesquieu, were equally learned in the condition of the Greek States, during the Peloponnesian war, a condition exactly similar to what yours would be, as described by the great Thucydides. The individuals of it would there learn, that those demagogues, who, from restlessness of temper, or ambition of making themselves conspicuous above others, plunged their countries into disorders and calamities, were often the first to fall by the hands of their countrymen ${ }^{19}$. "

La réputation de Thucydide en tant qu'autorité au sein des parlements permet d'idéaliser, dans le dernier quart du XVIII ${ }^{\mathrm{e}}$ siècle, la fondation de la démocratie moderne en Amérique. L'esprit bourgeois issu de la Révolution en était le catalyseur. Sa contrepartie, dénoncée comme cauchemardesque, s'est trouvée illustrée au moment de la Terreur (1794), lorsque Levesque travaillait à son Thucydide.

Un siècle et demi après, durant le deuxième quart $\mathrm{du} \mathrm{Xx}^{\mathrm{e}}$ siècle, les idéaux de la démocratie jeffersonienne perdaient la netteté transparente de leur forme originaire et classique.

"The past is never dead. It's not even past ", affirme William Faulkner dans son ouvre Intruder in the Dust $(1948)^{20}$. Dans les contes et les histoires composés pendant les années $1920^{21}$, Faulkner condense dans la formule « a dream dreamed by Thucydides " l'évocation de l'idéal d'harmonie qui allie raison, justice et beauté, notamment figuré sur le frontispice classique symbolisant la splendeur athénienne de la polis. C'est ainsi qu'il conçoit le siège du Palais de Justice, centre et fondement de la vie communautaire en milieu rural au Mississipi, parce que son village reproduit l'icône du Lycée de l'Université22. Dans ce jeu, par lequel la fiction dialogue avec la réalité, se dissipe néanmoins l'éclat de l'idéal de l'héritage démocratique jeffersonien, obscurci par l'air noirci des fumées de tabac émanant de citoyens qui s'y rassemblent.

Le romancier exprime un désenchantement encore plus grand dans sa critique acérée des malheurs vécus pendant la guerre, en 1943, prophétisant dans une lettre à son beau-fils Malcolm, en pleine célébration du 4 juillet :

"A change will come out of this war. If it doesn't, if the politicians and the people who run this country are not forced to make good the shibboleth they glibly talk about freedom, human rights, then you young men who live through it will have wasted your precious time, and those who don't live through it will have died in vain ${ }^{23}$."

19 P. Force, American Archives, Fourth Series, volume 1, 1837, p. 1417.

20 D. PARK Jr., "History's Catch-22 : The Peloponnesian War ", The History Teacher, 5.4 (1972), p. 27.

21 The Hill (1922) et Nympholepsy (1925).

22 Th. L. McHaney, "First is Jefferson : Faulkner shapes his domain ", Mississippi Quarterly 57.4 (2004), p. 516-517.

23 J.D. Anderson, "William Faulkner. A heart in conflict with itself », Chautauqua, 1998, [http://pages.emerson.edu/faculty/J/JohnAnderson/efaulkn.htm]. 
En 1950, lors de la cérémonie de remise du prix Nobel de Littérature, il a ainsi résumé de manière incisive sa pensée sur l'angoisse humaine en temps de guerre froide : "There are no longer questions of the spirit. There is only the question : When will I be blown up ? 24 "

Juste à cette occasion-là, à travers les analyses qui se développent entre Louis J. Halle en 1952-1955 et George Kateb en 1964, le jeu des voix qui composent des harmonies en écho au discours thucydidéen en Amérique change de tonalités dominantes. En 1952, l'Amérique avait à soupeser la décision qui devait la conduire à assumer, comme étant sa mission historique, les responsabilités de l'hégémonie mondiale. En 1964, avec l'empire américain déjà en pleine expansion, les leçons de Thucydide attirent l'attention sur les vicissitudes qui mènent de la Crise des Missiles à la guerre du Vietnam. Par la lecture de George Kateb, l'appréciation de la valeur exemplaire de l'histoire de Thucydide évolue au rythme de la ronde moderne de nos idéologies! Tout au début du XIX ${ }^{\mathrm{e}}$ siècle, Chateaubriand avait fait une réflexion similaire, mais en un sens plutôt opposé, sceptique, sur la (l'in)capacité ou la (l'in)disposition des hommes à écouter les leçons de l'histoire : "Thucydide retraça avec sévérité les maux causés par les dissensions politiques, laissant à la postérité des exemples dont elle ne profite jamais $^{25}$."

Dans les années 1990, les aspirations du " postmodern Thucydides ${ }^{26}$ " étaient déjà quelque peu ébranlées, et les milieux académiques commençaient à déplorer le déclin de leur influence auprès du staff gouvernemental américain, du fait même des abus de leur recours aux idées thucydidénnes ${ }^{27}$. On essaya alors de renouveler la figure moderne d'un Thucydide sage conseiller politique.

Gregory Crane rapporte, dans Thucydides and the ancient simplicity ${ }^{28}$, qu'au cours des premiers mois de la Première Guerre mondiale fut représentée à l'université de Toronto une mise en scène du Dialogue des Méliens, figurant les nations alors en guerre en costumes contemporains : aux Allemands fut confié le rôle d'Athènes, aux Britanniques celui de Sparte et aux pauvres Belges celui de l'infortunée Mélos.

24 M. Mandelbaum, "The bomb, dread, and eternity ", International Security, 5.2 (1980), p. 4.

25 Nous avons abordé cette analyse concernant la période de la guerre froide dans notre article "O General Marshall em Princeton, Tucídides na Guerra Fria », História da Historiografia, número 02 (2009), p. 101-115.

26 Formulées par W.R. Connor, "A post modernist Thucydides ? " Classical Journal 72.4 (1977), p. 289-298.

27 Voir l'article de L. Johnson-BagBY, "The use and abuse of Thucydides, in international relations ", International Organization 48 (1994), p. 131-53, et celui de D. WeLCH, "Why international relations theorists should stop reading Thucydides ", Review of International Studies 29 (2003), p. 301-320.

28 G. CRAne, Thucydides and the Ancient Simplicity : the Limits of Political Realism, Berkeley, University of California Press, 1998, p. 1. 
Or, dans l'œuvre où il rappelle cet épisode, Crane articule, lui aussi, une intrigue mélienne configurant une autre tragédie thucydidéenne, cette fois en la projetant dans les temps de la guerre civile américaine, juste en l'année 1864, au moment de la prise d'Atlanta par les forces de l'Union. Dans les messages échangés par William T. Sherman avec le commandant confédéré John Bell Hood et, ensuite, avec le Conseil de la ville d'Atlanta, Crane reconnaît les personnages du Dialogue des Méliens rapporté par Thucydide ${ }^{29}$. Dans les arguments de Sherman résonneraient en dialecte yankee les voix du realism power politics des thèses athéniennes, contre quoi s'étaient élevées, en des échos dignes de Mélos, d'abord l'indignation des inquiétudes humanistes, morales et religieuses du commandant confédéré Hood, ensuite les doléances du maire et du Conseil d'Atlanta. L'interprétation proposée par Crane pour comparer, sur le plan conceptuel, le dialogue entre Sherman et Hood avec le Dialogue mélien, chez Thucydide, conduira, pour l'histoire moderne, à une meilleure connaissance de la " classical realist tradition »: le know how militaire consacré par Sherman en serait le relais thucydidéen qui permettrait d'établir le pont reliant, d'un côté, « Machiavel et Hobbes » et, de l'autre côté, "Morgenthau et Kissinger ${ }^{30}$ ".

Que Sherman et Hood actualisent la mémoire de Thucydide au milieu de la guerre civile américaine répond en écho à un exercice élaboré dans le cadre de la culture érudite académique frappée, dans les années 1990, par les désastres de la Guerre du Golfe. On ne retrouve cependant aucune référence à Thucydide et à son histoire dans aucun des documents qui relatent l'épisode ${ }^{31}$, ni même dans la bibliographie qui s'y rapporte $^{32}$. Pour partiellement similaires à ceux de Thucydide que soient les formules

29 Ibid., p. 24.

30 "Indeed, Thucydides continues to occupy a privileged position as the first serious text on international relations and the founding document of the "classical realist" tradition that is exemplified by Machiavelli, Hobbes, Morgenthau, and Kissinger. Within this tradition, Sherman, practitioner and even theorist of total war, offers a useful bridge between classical Greece and the late twentieth century » (ibid., p. 22).

31 Voilà tout ce que Crane nous dit à ce propos : "Whether or not Sherman read Thucydides at West Point (he probably didn't - the United States military academy was an outstanding school for engineers but devoted surprisingly little time to history), his attitude toward the use of power and the practice of warfare owes much to the tradition that Thucydides inaugurated"(ibid., p. 23).

32 Je n'ai rencontré aucun vestige thucydidéen dans toute la bibliographie que j'ai pu consulter : A.J. BAILEY, War and Ruin. William T. Sherman and the Savannah Campaign, Wilmington, Scholarly Resources, 2003 ; R.S. Bonds, War Like The Thunderbolt. The Battle and Burning of Atlanta, Yardley, Westholme, 2010 ; S.E. Bower, "The theology of the battlefield : William Tecumseh Sherman and the U.S. civil war ", The Journal of Military History 64.4 (2000), p. 1005-1034 ; L.M. BRADY, "The wilderness of war : nature and strategy in the american civil war ", Environmental History 10.3 (2005), p. 421-447 ; A. CASTEL, "Liddell Hart's "Sherman" : propaganda as history ", The Journal of Military History 67.2 (2003), p. 405-426 ; E. CAudill and P. Ashdown, Sherman's March in Myth and Memory, New York, Rowman \& Littlefield Publishers, 
et les topoi rhétoriques de la culture guerrière employés par les deux commandants de la

2009 ; M.B. Chesnut, A Diary from Dixie, edited by I.D. Martin and M.L. Avary, New York, D. Appleton and Company, 1906 ; D. CoffeY, John Bell Hood And the Struggle for Atlanta, Abilene, McWhiney Foundation Press, 1998 ; H. DeEdes, Sketches of the South and West or Ten Months' Residence in the United States, Edinburgh and London, William Blackwood and Sons, 1869 ; M. Fellman, Citizen Sherman. A Life of William Tecumseh Sherman, New York, Random House, 1995 ; F. FreIDEL, "Resenha crítica de "The general who marched to hell" de Earl Schenck Miers ", The Pennsylvania Magazine of History and Biography 76.1 (1952), p. 115-116 ; G.W. GALLAGHER, "Resenha crítica de "civil war command and strategy" de Archer Jones ", The Journal of American History 80.2 (1993), p. 687-688 ; G.W. Gallagher, «Resenha crítica de "The White Tecumseh" de Stanley P. Hirshson ", The American Historical Review 103.4 (1998), p. 1325 ; M.R. Grandstaff, "Resenha crítica de "Citizen Sherman" de Michael Fellman ", The Journal of Military History 60.3 (1996), p. 553-554 ; E. HaGERMAN, Edward, "Resenha critica de "The Destructive War" de Charles Royster ", The Journal of American History 79.3 (1992), p. 1184-1186 ; V.D. Hanson, The Soul of Battle, New York, Anchor Books, 2001 ; E.R. Henken, "Taming the enemy : Georgian narratives about the civil war ", Journal of Folklore Research 40.3 (2003), p. 289-307 ; S.P. HirshsOn, The White Tecumseh. A Biography of General William T. Sherman, New York, John Wiley \& Sons, 1997 ; H.M. JONES, "The literature of Virginia in the seventeenth century ", Memoirs of the American Academy of Arts and Sciences, New Series, 19.2, (1946), p. 1-47; C. LEWIS, "The civil war : killing and hallowed ground ", The Sewanee Review, 103.3 (1995), p. 414-425 ; B.H. Liddel Hart, Sherman. Soldier. Realist. American, New York, Da Capo Press, 1993 ; M.B. LuCAS, Sherman and the Burning of Columbia, Columbia, University of South Carolina Press, 2000 ; J.F. MarszaleK, Sherman : A Soldier's Passion for Order, New York, FreePress, 1993 ; J.B. McCarley, The Atlanta Campaign, Atlanta, Cherokee Publishing Company, 1989 ; R.M. McMurry, John Bell Hood and the War for Southern Independence, Lexington, The University Press of Kentucky, 1982 ; J.M. McPherson, "Blitzkrieg in Georgia ", New York Review of Books 30 (2000), p. 27 ; E.S. Miers, The General Who Marched To Hell. William Tecumseh Sherman and His March to Fame and Infamy, New York, Alfred A. Knopf, 1951 ; J. Miller Jr., "Resenha crítica de "Sherman's March Through The Carolinas" de John G. Barrett ", The Journal of Southern History 23.3 (1957), p. 397-398 ; G.F. Milton, "Resenha crítica de "The general who marched to hell" de Earl Schenck Miers ", The American Historical Review 57.3 (1952), p. 699-700 ; J.L. Morrison Jr., "The Best School ». West Point, 1833-1866, Kent-London, The Kent State University Press, 1998 ; M.D. Pearlman, Warmaking and American Democracy. The Struggle over Military Strategy, 1700 to the Present, Lawrence, University Press of Kansas, 1999 ; Ch. RoYster, The Destructive War, New York, Vintage Books, 1993 ; E.D. SAMET, Willing obedience : citizens, soldiers, and the progress of consent in America, 1776-1898, Stanford University Press, 2004 ; R.H. SEwell, "Another kind of war ", Reviews in American History 24.3 (1996), p. 426-431 ; W.T. SHERMAN, William Tecumseh, "Possible presidents ", The North American Review, 146.377 (1888), p. 416-423 ; W.T. Sherman, Home Letters of General Sherman, edited by M. A. DeWolfe Howe, New York, Charles Scribner's Sons, 1909 ; W.T. Sherman, Memoirs of General William T. Sherman, New York, Da Capo Press, 1984 ; C.L. Symonds, « Resenha crítica de "The war within the Union High Command" de Thomas J. Goss ", The American Historical Review 110.3 (2005), p. 796-797 ; E. Tidball, "General Sherman's March 
guerre civile, pourquoi faudrait-il évoquer, dans les drames de l'épisode d'Atlanta 1864, le vieux fantôme thucydidéen, en affirmant que son esprit s'y trouverait présent ?

Analysant les arguments opposés de Sherman et de Hood, Crane construit son interprétation de l'événement où il apprécie (ou méprise) la dialectique (ou la rhétorique) de l'un et de l'autre. Les jugements exprimés sur les propos du Confédéré distillent quelque acidité, sinon de l'hostilité, pour en dénoncer des aspects suspects. Quant à ceux qui portent sur les propos du Yankee, ils expriment la mansuétude, voire la sympathie, et justifient chez lui de bonnes raisons. Ainsi, chez Hood, Crane discrédite systématiquement des erreurs de commandement qu'il attribue à une scolarité déficiente, camouflant une morale douteuse sous une rhétorique spécieuse ${ }^{33}$. Chez Sherman, au contraire, Crane veut identifier un discernement si "réaliste ", dans le traitement des affaires militaires, qu'on pourrait mieux apprécier positivement ses mérites, en raison de sa cohérence et de son efficacité exceptionnelle. Il s'agirait là d'une perception si aiguë et si précise de toutes les contraintes qui sont imposées par la guerre, une conscience douée d'une telle " clairvoyance logique " qu'elle nous permettrait même d'en apercevoir des actions vertueuses dans ce qu'on aurait au contraire dû dénoncer comme les pires des cruautés. Sa "dureté » et son "impiété » ne vont pas sans quelque " candeur ». Sa " sauvagerie " et sa "férocité " révèlent plutôt une " rationalité libérée des passions ". De sorte que l'exercice de "la force et de la violence " est chez lui " judicieux " et même " modéré ", sinon " tendre ou suave ${ }^{34}$ ». Il pourrait quelquefois tomber dans des excès, mais sans qu'il y ait jamais une bonne raison, parce qu'il serait alors " juste et dignement » irrité en réagissant, " exaspéré » à cause des " outrages » et des " abus " rhétoriques de son adversaire dans la discussion, lequel se déguiserait en champion d'une éthique humanitaire avec de " faux airs chrétiens ${ }^{35}$ ", pour dissimuler la faillite de son argumentation " fautive " et "injuste " ${ }^{36}$. Sherman peut encore, selon Crane, jouer avec l'ironie et même le «sarcasme » qui lui permettent de " mépriser » les ressources frauduleuses de son adversaire ; mais aussitôt il se lasse et clôt une discussion

through Montana ", Montana: The Magazine of Western History 44.2 (1994), p. 46-59; J.B. Walters, Merchant of Terror. General Sherman and Total War, Indianapolis-New York, The Bobbs-Merril Company, 1973 ; Ch.E. VetTeR, Sherman : Merchant of Terror, Advocate of Peace, Gretna, Pelican Publishing Company, 1992 ; R.F. WeIgley, "War as apocalypse in nineteenth-century America ", Reviews in American History 20.3 (1992), p. 326-330.

33 Crane (1998, p. 25-26). Voir cependant ce que dit Richard M. McMurry : "Hood's career had never been fairly evaluated and his place in Confederate history was misunderstood. He was a victim of historians who assume that he could do nothing right and that his chief critic could do no wrong" (MCMurRY, 1982, p. IX).

34 G. Crane, Thucydides and the Ancient Simplicity : the Limits of Political Realism, op. cit., p. 22-23, 25, 28-29.

35 Ibid., p. 26.

36 Ibid., p. 27. 
oiseuse, bien persuadé qu'il est de sa position de force, alors que son adversaire s'efforce de poursuivre en (dé)voilant tout au contraire la faiblesse de sa propre position ${ }^{37}$.

Dans son ouvrage antérieur, The Blinded Eye, Gregory Crane avait déjà encadré le mode de perception de la réalité historique thucydidéenne dans la perspective de la rationalité scientifique, en rapprochant les opérations cognitives de l'historien athénien de l'esprit mathématique d'Archimède ${ }^{38}$. En ce temps-là, dans la première moitié des années 1990, où l'identité thucydidéenne courait le risque de se perdre dans la vogue d'un postmodernisme porté à nier sa référence aux faits et sa rationalité, Crane restaure le prestige de la scientificité thucydidéenne. Par le rapprochement, opéré cette fois dans Thucydides and the Ancient Simplicity, avec le réalisme militaire défendu par Sherman, Crane établit un autre lien pour consolider les paramètres d'un tel encadrement, avançant alors la thèse selon laquelle, par la simple orientation d'un calcul strictement rationnel, il est possible de réconcilier aussi harmonieusement les propositions de l'éthique humanitaire de Sherman avec la tradition du réalisme politique, et cela même en dépit de l'inflexibilité de la power politics qu'il pratique. Au terme de son évaluation des raisons d'agir du chef yankee dans la guerre civile américaine, Crane compose presque une apologie de Sherman. Parce qu'il est beaucoup plus lucide qu'Achille (chez Homère $^{39}$ ) et que les Athéniens (chez Thucydide ${ }^{40}$ ), Sherman reste toujours impassible pour ne jamais perdre ni la raison ni l'humanité de ses actes, atteignant ainsi un niveau supérieur dans la conduite de la guerre, grâce auquel il défend le principe de la préservation de l'ordre comme fondement absolu de la civilisation ${ }^{41}$. Ce sont là les aspects du réalisme éthique et humain de Thucydide, dévoilé quelques années plus tôt par l'herméneutique straussienne de Clifford Orwin, à laquelle Crane fait expressément référence ${ }^{42}$. Le réalisme de Sherman avait donc une affinité avec celui de Thucydide, dont il apparaît comme un "descendant ", tous deux raisonnant selon une rhétorique bonne ou adaptée, parce que déclarée, sincère et honnête, sans perdre son " humanité ». On aurait dans la performance rhétorique de Sherman une sorte d'épiphanie discursive du civisme, de la justice et de la piété ${ }^{43}$.

Par les exercices d'osmose exégétique rapprochant (les mémoires de) Sherman et Thucydide, l'esprit du ktema es aei est conduit, lui aussi, vers la guerre civile américaine :

37 Ibid., p. 28.

38 F. MURARI Pires, "Thucydidean modernities : history between science and art ", in Brill's Companion to Thucydides, op. cit., p. 837 ; F. Murari PIRES, « Ktema es aei : a prolixidade do silêncio tucidideano ", Anos 90 (2003), p. 104-106.

39 G. Crane, Thucydides and the Ancient Simplicity : the Limits of Political Realism, Berkeley, University of California Press, 1998, p. 30-31.

$40 \quad$ Ibid., p. 31-32.

41 Ibid., 1998, p. 30.

42 Ibid., p. 32.

43 Ibid., p. 32-35. 
il brûle alors dans les flammes infernales de Columbia et enfonce dans les marais noircis d'Ebenezeer Creek. Ainsi aimanté par l'attraction de la persona de Sherman, tout un pandémonium de concepts et de théories gravite autour du débat concernant la discussion du phénomène de la guerre dans l'encadrement de la "classical realist tradition ". Il s'ensuit alors une ronde herméneutique de (ré)visions idéologiques dont chaque pas est chorégraphié selon les perceptions par lesquelles chaque intervention critique (ré) articule diversement les arguments de l'enchaînement constitutif du débat.

Le pandémonium conceptuel des perceptions assombrit la nature du phénomène de la guerre par une prolifération de la nomenclature du phénomène : " fatalistic intellectual naturalism "; " existentional " versus " civilizational war "; "Clausewitzean " versus " Jominian "; " not war, rather statesmanship "; " directed severity "; " punitive warfare "; " political religion "; " civic religion "; " civic necessity "; " willing, liberal obedience " versus " autocratic "; " incarnation of destructive war "; « moral totalism »; « creative destroyer »; « limited » versus « total war »; « indirect approach »; « symbolic, psychological warfare »; " psychological warfare of moral totalism "; " psychological or terror warfare "; " terrorizer "; " consciously applied terror "; « a war of mass terror "; "war of extermination»; " genocide».

Le personnage est encadré par des figurations imaginaires opposées, évaluées en fonction de leur performance guerrière : "uncle Billy ", ami idolâtré par les soldats, versus commandant froid, dur et calculateur, sinon cynique ; guerrier génial versus fou, égocentrique exalté ou mélancolique dépressif, névrosé ; zélé défenseur de la loi dans ses devoirs militaires versus commandant permissif et négligent ou cynique et dissimulé ; dévoué à la préservation de l'ordre, avocat de la paix, prophète armé et ange exterminateur, Américain typique, réaliste, idéaliste versus satrape militaire, barbare ; gentil et charitable versus brutal et impitoyable ; ou même abolitionniste, libérateur (des Noirs) versus individu sans scrupules, voire raciste ; héros ou saint versus monstre ou démon.

Et la ronde des appréciations irréfléchies ${ }^{44}$ fait divaguer les dommages du phénomène guerrier à travers diverses formulations en appréhendant en la personne de Sherman le symbole de la guerre en des termes (réalité naturelle, totale, universelle ; caractère national, essence américaine ; pathologie ; apocalypse ; terrorisme) qui tournent dans un carrousel d'idéologies au gré des lieux sociaux des historiens (ou des politologues) qui les produisent.

Comme le dit le romancier :

« And so the war had come down to words. It was fought in terminology across a table. It was contested in sentences. Entrenchments and assaults, drum taps and bugle calls,

44 Jusqu'à aboutir, chez un interprète, à des formulations étranges : "They shot every dog in their path, not because they hated pets or Southerners in general, but because they were furious that such hounds had hunted down runaway slaves and escaping Union prisoners " (V.D. Hanson, The Soul of Battle, New York, Anchor Books, 2001, p. 159). 
marches, ambushes, burnings, and pitched battles were transmogrified into nouns and verbs. [...] Language is war by other means ${ }^{45}$."

\section{«Les yeux et les mains»}

"All men's faces are true, whatsome'er their hands are»

Voilà ce que Shakespeare fait dire à l'un des personnages d'Antoine et Cléopâtre 46 .

Auparavant déjà, parmi les humanistes italiens du Quattrocento (Luigi Pulci, Poggio Bracciolini) ${ }^{47}$, circulait une fable populaire avec un message équivalent. Deux oiseaux en cage échangent sur le destin qui les attend en voyant leurs semblables tués par leur maître. L'un d'eux, impressionné par les larmes qui coulent des yeux de l'homme, nourrit de bons espoirs : peut-être que la compassion ainsi affichée leur épargnera la même infortune. L'expérience pleine de sagesse du plus vieux, cependant, détruit ces illusions en avertissant : "Regarde les mains, pas les yeux ».

Machiavel, reprenant cette anecdote dans les préceptes destinés à instruire son "Prince », prend à son compte la leçon d'art politique qu'elle contiendrait :

Comme " gli uomini in universale giudicano più agli occhi che alle mani, perchè tocca a vedere a ciascuno, a sentire a pocchi ", alors " ognuno vede quel che tu pari, pocchi sentono quel che tu sei ». Que le Prince sache donc bien (dis)simuler les manifestations de ses qualités et de ses vertus de manière à être vu "tutto pietà, tutto fede, tutto umanità, tutto integrità, tutto religione ». Qu'il concentre tout le zèle de ses entreprises à "vincere e mantenere lo Stato ", sans trop se soucier de scrupules quant aux moyens et aux ressources employés, car « i mezzi saranno sempre giudicati onorevoli, e da ciascuno lodati : perchè il volgo ne va sempre preso con quello che pare, e con l'evento della $\operatorname{cosa}^{48}$. »

De cette manière, la (con)science herméneutique par laquelle les historiens jugent les (dis)simulations à travers lesquelles les actes historiques sont accomplis se perd, trompée par la séduction de l'apparence " honnête " des visages affichée par le personnage. De sorte que l'(in)attention de la critique est donc aimantée par la figuration vertueuse du personnage, sans tenir compte de ce qu'on pourrait en percevoir de terrible, d'exécrable ou d'affreux d'après ses actions mêmes.

45 E.L. Doctorow, The March. A Novel, New York, Random House, 2005, p. 348.

46 Act II Scene 6 (Shakespeare, Dramatic Works v. IV, p. 501).

47 M. Viroli, Machiavelli, Oxford, Oxford University Press, 1998, p. 67.

48 N. Machiavelli, Il Principe, edited by L. Arthur Burd, Oxford, At the Clarendon Press, 1968, p. 306-307. 
La guerre n'existe pas en soi. Elle est ce que les hommes en font en la pratiquant. La guerre n'est que l'image spéculaire de ce que sont les hommes. Si elle est dénoncée comme "folie ", c'est à cause de leur démence ; si elle est dénoncée comme "agression et tuerie ", c'est à cause de leur brutalité ; si elle est dénoncée comme "flagellation ", c'est à cause de leur despotisme; si elle est dénoncée comme "cruauté ", " destruction ", "désolation" et "massacre ", c'est à cause de leur sauvagerie, de leur barbarie; si elle est dénoncée comme "peste ", " horreur ", c'est à cause de leur monstruosité ; si elle est dénoncée comme " terreur ", c'est à cause de leur banditisme; si elle est dénoncée comme " corruption ", c'est à cause de leur méchanceté ; si elle est dénoncée comme " impiété ", c'est à cause de leur perversité ; si elle est dénoncée comme "enfer ", c'est à cause de leur satanisme.

À travers tous ces modes de déviances se distingue l'excellence guerrière de William Tecumseh Sherman, conformant la réalité de la guerre (civile américaine) à l'image des caractéristiques de sa nature personnelle. Pour paraphraser Héraclite, dans l'individu humain, l'êthos ou caractère se confond avec le daimon personnel, nommé aussi (postérieurement) démon! Tant de dénominations pour que le Général Sherman reçoive la réputation qu'il mérite dans l'histoire ${ }^{49}$.

L'année après celle où Crane publie Thucydides and the ancient simplicity, Victor Davis Hanson poursuit sa croisade personnelle de " classical scholar " obsédé par le sujet de la guerre. Dans l'avancée qui parcourt The Soul of the Battle, la marche est rythmée au pas d'Épaminondas, de Sherman et de Patton. Visionnaire du passé, Hanson établit, en explorant les idiosyncrasies militaires liées à la persona de Sherman, l'équation par laquelle il entend révéler la vision (ou, à nous de le dire, le mirage) de la guerre en faisant la somme des deux éléments d'où résulterait la vérité (ou, encore à nous de le dire, la mystification) de ce phénomène :

- première variable de la shermania, la naturalisation de la guerre comprise comme foudre, tempête : "war, like the thunderbolt follows its laws [...]. You might as well reason with a thunderstorm ";

- deuxième variable de la shermania, l'idéalisation de la guerre associée à l'âme de l'armée: "There is a soul to an army as well as to the individual man ${ }^{50}$ ";

- formule résultant de la somme mystique opérée par transitivité commutative, l'àme de la guerre: "A rare thing indeed that arises only when free men march unabashedely toward the heartland of their enemy in hopes of saving the doomed, when their vast armies are aimed at salvation and liberation, not conquest and enslavement ${ }^{51}$."

49 Ainsi auguré par Sherman lui-même dans une lettre à Thomas Ewing du 13 août 1863 : "My children and children's children will now associate my name with their Country's History " (M. Fellman, Citizen Sherman. A Life of William Tecumseh Sherman, New York, Random House, 1995, p. 199.

50 V.D. Hanson, The Soul of Battle, op. cit., 2001.

51 Ibid., p. 5. 
Et ainsi Hanson évalue l'(illusion de) la guerre en ne regardant que les yeux qui la dissimulent, de façon à éviter de la juger par les mains qui la font. En associant obsession académico-militaire et piétés filiales, Hanson réalise sa catharsis personnelle : "The Soul of Battle " rachète la figure du père, "Sergeant William F. Hanson, not a violent man ", et cependant bombardier qui, obéissant et attentif au commandement de Curtis Le May, incendia de napalm la ville de Tokyo dans des raids aériens répétés durant la Deuxième Guerre mondiale, prouesse dont il s'enorgueillissait beaucoup ${ }^{52}$. Le discours académique, que l'aura de scientificité proclame comme étant objectif, exorcise le mal terrifiant de la guerre en l'extériorisant par rapport à ses agents, de sorte que, par les visions de Hanson, le concept de la guerre parvient, du purgatoire de la nature du phénomène, au paradis de sa transcendance, si infernale et répulsive que soit cette praxis de la guerre pour l'humanité.

Un an plus tard, juste au tournant du millénaire, dans un article d'historien militaire (ou vice-versa) ${ }^{53}$, l'auteur fait (res)surgir de nouvelles caractérisations de Sherman en tant que «type religieux » : « visionnaire » et " prophète » du «credo » yankee, proclamant la «sainteté de la Nation ", ainsi métamorphosée en concept pour rendre compte de l'" american exceptionalism " et son esprit " expansionniste » destiné à commander l'actuel " peuple de Dieu, agent de la Providence » dans le monde contemporain. Par ce débordement d'ingrédients " théologiques » et au moyen d'une rhétorique « militaire », on projette sur Sherman l'aura transcendante qui fait de lui le champion de «la victoire des forces du bien contre celles du mal ». Annonce de voix sinistres que le nouvel occupant de la Maison Blanche fera résonner dans les années suivantes.

Au temps du gouvernement Bush, déjà stigmatisé par le 09/11, Angelo Codevilla - sorte de Super Hawk descendu en Amérique avec des pouvoirs spéciaux illustrant une vision politique ultraconservatrice - se lance dans une campagne systématique ${ }^{54}$ par laquelle à la fois il s'en prend à l'administration présidentielle, en raison de son manque d'efficacité pour mettre un terme au mal, et il martèle les oreilles du peuple américain

52 Ibid., p. 1-5.

53 S.E. BOwer, "The theology of the battlefield : William Tecumseh Sherman and the U.S. civil war ", The Journal of Military History 64.4 (2000), p. 1005-1034.

54 A. Codevilla, "Wake-up call ", Claremont Review of Books I.2 (Winter 2001), $10 / 02 / 2001$; A. Codevilla, "What it will take to win. How to win - and how not to win - America's war on terrorism ", Claremont Review of Books II.1 (Fall 2001), 28/11/2001 ; A. Codevilla, "Some call it Empire. Imperial delusions are no substitute for defeating our enemies ", Claremont Review of Books V.4 (Fall 2005), 21/11/2005 ; A. CodeVILla, No Victory, No Peace, Lanham, Rowman \& Littlefield, 2005 ; I. Khawaja, "Victory : means and end (Symposium Angelo Codevilla's No Victory, No Peace) », Reason Papers 28 (Spring 2006), p. 7-18 ; R. Spengler, "Angelo Codevilla and William Tecumseh Sherman (Symposium Angelo Codevilla's No Victory, No Peace) ", Reason Papers 28 (2006), p. 35-42 ; R.T.A. LonG, "A Florentine in Baghdad : Codevilla on the war on terror ", Reason Papers 28 (Spring 2006), p. 9-33. 
pour le (ré)éduquer dans le sens d'une conception légitime de la guerre, nécessaire pour extirper de la face du monde le nouvel ennemi qui perturbe la prospérité des Américains dans leur way of life particulier : les régimes arabes qui soutenaient " l'antiaméricanisme ", fondement réel dont le terrorisme ne serait qu'un épiphénomène. Une fois la vraie cause du mal identifiée, tout se réduisait à tuer l'ensemble des personnes qui le composent. Codevilla se souvient donc de la leçon du général yankee durant la guerre civile : à Atlanta, Sherman recommandait d'exterminer quelque 300000 Confédérés. Codevilla se fait l'écho de cette proposition, en revendiquant le même principe de " bonne guerre » et en réclamant l'équivalent contre les régimes arabes. Avec Codevilla, dès la première décennie du deuxième millénaire, renaît l'esprit de William Tecumseh Sherman : incarnation de la guerre, son démon exterminateur.

Dans le tourbillon des obsessions guerrières revivifiées en Amérique au tournant du millénaire, le discours académique, en ressuscitant l'esprit de Sherman, revigore son discours belliqueux, en l'alimentant encore et toujours avec le sang de Thucydide, dont il se sert comme d'une drogue et dont il est incapable de se libérer, à l'instar d'un vice.

W.H. Auden, angoissé par les souffrances au moment de l'éclosion de la guerre en Europe, évoque lui aussi des souvenirs thucydidéens ${ }^{55}$. Dans ses divagations et flâneries dans les rues de New York, affleure le poème September 1, 1939. Entrecoupé d'allusions diverses, le souvenir du ktema es aei ${ }^{56}$ fait surgir ces vers :

« Exiled Thucydides knew

All that a speech can say

About Democracy,

And what dictators do,

The elderly rubbish they talk

To an apathetic grave ;

Analysed all in his book,

The enlightenment driven away,

The habit-forming pain,

Mismanagement and grief :

We must suffer them all again ».

Cependant, l'auteur ne tenait pas son poème en très grande estime. Il lui déplaisait même au point de le rejeter dans les années qui suivirent. En se référant au vers qui deviendrait très célèbre par la suite ("We must love one another or die »), il s'est désavoué : "That's a damned lie! We must die anyway ", il en vint à critiquer le poème en entier, parce que « infected with an incurable dishonesty». Telle est la conclusion

55 L. Perillo, "Auden's 9/1/3 "9, The American Poetry Review 31.5 (2002), p. 28-29.

56 Epistle to a Godson: "If what is to happen occurs according to what Thucydides defined as "human", we've had it " (M.A. FitzSIMONS, "Thucydides : history, science and power", The Review of Politics, 37.3 [1975], p. 377-397.) 
implacable que le poète déduit de son équivoque : "The most dishonest poem I have ever written ${ }^{57}$. " Et pourtant, le poème eut une destinée inattendue lors de la campagne présidentielle de 1964 : les derniers vers, travestis en propagande électorale ${ }^{58}$, furent récités par Lyndon Johnson dans une publicité télévisée intitulée Daisy. Intérêt aussi déplacé que pervers, paré d'une aura poétique abusive, dans la mesure où il profitait d'une bévue de la part de son adversaire (Barry Goldwater), qui avait suggéré, de manière certes calamiteuse et imprudente, que la meilleure manière d'en finir avec la guerre du Vietnam serait de renouer avec le champignon atomique dans les champs asiatiques ${ }^{59}$. En apprenant cela, le poète aurait dit : «I pray that I never be memorable like that again ${ }^{60}$."

Quelle prière dirait à son tour Thucydide de nos jours? Quelles vérités (ou mensonges) les plus (in)dignes des tragédies (ou des farces) continuons-nous à proclamer en tirant profit du prestige du ktema es aei thucydidéen ? Persisterons-nous à maculer de sang nos mains en trempant nos desseins dans des sacrifices offerts au nom de la voix que nous faisons résonner en tant que la parole véridique venue de l'âme de Thucydide? Il faudrait que les modernes assument en leur propre nom et en fonction de leur propre (ir)responsabilité toutes les (dé)raisons et toutes les (im)moralités connexes aux angoisses (ou, au contraire, aux jubilations) de leurs obsessions guerrières. Si l'on parvenait alors à restaurer les contours silencieux de la parole originale, en laissant, comme l'a demandé le philosophe en écho à l'Évangéliste, " les morts enterrer leurs morts », on pourrait alors saluer l'historien ancien par le vers du poète : lie quiet, Divus! En effet,

there are times when silence is imperative for us

to listen the music behind the raindrops ${ }^{61}$.

Francisco Murari Pires

Professeur Émérite,

Département d'Histoire,

Faculté de Philosophie Lettres et Sciences Humaines,

Université de São Paulo, Brésil

Av. Itacira 2603,

Planalto Paulista,

São Paulo, Brasil, CEP 04061-003

murari@usp.br

57 S. Hynes, "The voice of exile : Auden in 1940 ", The Sewanee Review 90.1, 1982, p. 31-52 ; L. Perillo, "Auden's 9/1/39 ", The American Poetry Review 31.5, 2002, p. 28.

58 "We must love each other or we must die " (ibid., p. 28).

59 Ibid., p. 28. Voir http://www.livingroomcandidate.org/commercials/type/fearStan.

60 L. Perillo, "Auden's 9/1/39», The American Poetry Review 31.5, 2002, p. 28.

61 T. Angelopoulos, The Suspended Step of the Stork, 1991. 